Bull. Fac.Agric., Cairo Univ. 66: 297-306 (2015).

\title{
GENETIC VARIATION AND ASSOCIATIONS BETWEEN SOME AGRONOMIC, CHEMICAL SEED COMPONENTS AND SEEDLING VIGOR CHARACTERS IN SOME COTTON VARIETIES
}

(Received: 22.10.2015)

\author{
By \\ A. M. Abd El-Moghny, R. H. A. O. Gibely and M. S. Max \\ Cotton Breeding Research Section, Cotton Research Institute, \\ Agricultural Research Center, Giza, Egypt.
}

\begin{abstract}
Agronomic and seed chemical characters of cottonseed play a prime role in seedling vigor establishment for cotton plant to obtain the maximum stand and better growth. Nutritional components in the seed play a very important role in early seedling developmental stage to produce healthy plants. The present study was conducted to investigate the genetic variability and relationship among agronomic, chemical components and seedling vigor characters of eight Egyptian cotton varieties (Gossypium barbadense) classified into two categories according to their fiber quality properties (long and extra long staple). The results showed highly significant genotypic variation for all the studied characters, which reflect the genotypic variability between the studied genotypes. Broad sense heritability ranged from moderate to high values for all the studied characters. Genetic divergence $\left(\mathrm{D}^{2}\right)$ showed highly significant dissimilarity between the two categories of Egyptian cotton varieties, except between the extra long staple category. There was a highly significant and positive association between protein content and seed volume, lint index and seed index, also between oil content and carbohydrate content (0.583). While, seed oil percentage was not correlated with seed properties except lint percentage and a highly significant and negative correlation between seed protein and oil content. Most of the studied characters showed highly significant dissimilarity coefficients between and within these studied characters, which reflect the genetic variation background of these genotypes. Significant positive correlation and dissimilarity coefficients among and within these studied characters suggest that selection may be useful for the enhancement of the correlated characters.
\end{abstract}

Key words: Gossypium barbadense, cottonseed components, seedling vigour, growth ratio, dissimilarity coefficient, correlation.

\section{INTRODUCTION}

Cotton is an important fiber crop and plays a vital role as a cash crop in commerce of many countries. Cotton, also known as "King of fibers" plays a remarkable role in economy. Seed quality plays an important role in the production of agronomic and horticultural crops. Characteristics such as trueness to variety, germination percentage, purity, vigor, and appearance are important to farmers planting crops and to homeowners establishing lawns and gardens. Achieving and maintaining high seed quality is the goal of every professional seed produce (Pahlavan et al., 2008).

Agronomic seed traits such as the seed index, the seed volume and seed density are all determinants of seed vigor in cotton, all strongly influence crop stands, growth and seed cotton yield. The seed index (weight of 100 seeds) is related to seed cotton yield, while the number of seeds per boll is recognized as the largest contributor to lint yield after the number of bolls per unit area. The desirability of a larger number of seeds per boll has been emphasized as a requirement for greater seed surface areas, and hence lint production within the boll (Rahman et al., 2005).

The content of oil and protein in cotton seeds as well as other species is associated with the size of the seed that has a considerable contribution to crop yield. In addition, seed size plays a major role in germination and establishment of uniform stand of healthy, vigorous seedlings that are essential to achieving 
high yield. Some researchers reported that seed size in cotton had a great influence on the seed germination (Pahlavani et al., 2008 and 2009 and Groves and Bourland, 2010).

The cotton seed, is an important source of edible oil. Cottonseed oil is a cooking oil extracted from the seeds of cotton plant. Cotton seed is the second largest source of vegetable oil in the world. Cottonseed oil is typically composed of about $26 \%$ palmitic acid (C16:0), $15 \%$ oleic acid (C18:1), and $58 \%$ linoleic acid (C18:2). The relatively high level of palmitic acid provides a degree of stability to the oil that makes it suitable for high-temperature applications, but is nutritionally undesirable because of the low-density lipoprotein cholesterol-raising properties of this saturated fatty acid (Ashokkumar and Ravikesavan, 2011).

Cotton yield is a polygenic complex character, depends on several contributing characters coupled with varying environmental conditions. The knowledge of the relationship among various yield components need to be exploited successfully in order to determine the aspects of plant selection criteria. So, understanding the relationships between these complex characters like yield and its components is important for selection in any breeding programme. Also, the relationships between those yield characters and other economic characters like, chemical seed components and seedling parameters are important to select the most valuable characters. The correlation analysis reflects the correlated response of a particular character with its counterpart and provides a good index to predict the corresponding change which occurs in one character at the expanse of the proportionate change in the other character (Islam and Dilruba, 2013).

For cotton, the initial phases of seedling growth are fueled by the available nutritive reserves of the cotyledons, which are lipids and proteins. Lipids represent the most energy-dense storage compound of the quiescent cotton seed utilized during post-germination growth, so higher seed oil content would enhance seedling vigor by providing more chemical energy to the growing seedling (Snider et al., 2014).

The present study aimed to compare between eight Egyptian cotton varieties for their mean performance of some agronomic, chemical cottonseed components and seedlings vigor characters, estimate Mahalanobis $\mathrm{D}^{2}$ statistic between the eight Egyptian cotton varieties based on all the studied characters. Also, the study was extended to identify the relationships and dissimilarities between and within these characters.

\section{MATERIALS AND METHODS \\ 2.1.The field experiment}

Eight Egyptian cotton varieties (Giza 90, Giza 86, Giza 88, Giza 87, Giza 92 Giza 93, Giza 94 and Giza 96) belonging to Gossypium barbadense L. were reviewed origin, category, pedigree and characterization of these varieties are shown in Table (1). This trial was carried out at Sakha Experimental Station; Agricultural Research Center, Kafr El-Sheikh; Egypt, during the growing season of 2014. The experimental layout was a randomized complete block design (RCBD) with six replications. Each entry was grown in three rows of $4 \mathrm{~m}$ length, $70 \mathrm{~cm}$ apart and distance between plants within rows was $30 \mathrm{~cm}$. General agronomic and cultural practices recommended for cotton crop were adopted.

Samples of 50 random bolls from the upper, middle and lower parts of the plants were carefully handpicked, from each variety. These samples were ginned in order to record the following agronomic characters: boll weight (BW) in grams, seed cotton yield per 50 bolls (SCY) in grams, lint yield per plant (LY) per 50 bolls in grams, lint percentage (L \%), lint index (LI) and seed index (SI) expressed as the weight of 100 seeds. Seed volume (SV) was determined by displacement in $30 \mathrm{ml}$ absolute ethanol using the same 100 seed sample. Also, seed density was calculated as the ratio between seed weight and seed volume as describe by Groves and Bourland (2010).

\subsection{Pot experiment}

A pot experiment was conducted at the Cotton Physiology greenhouse, Cotton Research Institute, Agricultural Research Center, Giza, Egypt. The eight cotton genotypes were grown in plastic pots $(30 \mathrm{~cm}$ diameter) filled with loamy clay soil. The experiment was arranged in a randomized complete block design with six replications for each genotype, each replicate consists of six pots and each pot has one plant. After 7, 14 and 21 days after germination, data were recorded for growth ratio. After 21 days of germination, the plants were then spread on a paper for determination of root length (RL) in $\mathrm{cm}$, and shoot length $(\mathrm{SL})$ in $\mathrm{cm}$. Plants were cut into roots and shoots, and fresh root weight (FRW) in $\mathrm{g}$ and fresh shoot weight (FSW) in gm 
Table( 1) : Origin, pedigree and characterization of the eight Egyptian cotton varieties.

\begin{tabular}{|l|l|l|l|}
\hline Variety & \multicolumn{1}{|c|}{ Category } & \multicolumn{1}{|c|}{ Pedigree } & \multicolumn{1}{|c|}{ Characterization } \\
\hline Giza 90 & Long staple & Dandara / Giza 83 & $\begin{array}{l}\text { Large boll weight, high seed cotton } \\
\text { yield, high lint percentage, early and } \\
\text { low fiber quality. }\end{array}$ \\
\hline Giza 86 & Long staple & Giza 75 / Giza 81 & $\begin{array}{l}\text { Late maturity, high in yield characters, } \\
\text { and long staple fiber quality. }\end{array}$ \\
\hline Giza 94 & Long staple & Giza 86/10229 & $\begin{array}{l}\text { High yield, high lint percentage and } \\
\text { long staple fiber quality }\end{array}$ \\
\hline Giza 87 & Long staple & (Giza 77 / Giza 45) a & $\begin{array}{l}\text { Extra-fine extra-long staple fiber } \\
\text { quality, high g/tex and high yield. }\end{array}$ \\
\hline Giza 88 & Extra long staple & (Giza 77 / Giza 45)B & $\begin{array}{l}\text { Late maturity, high seed cotton yield } \\
\text { and extra long staple fiber quality. }\end{array}$ \\
\hline Giza 92 & Extra long staple & $\begin{array}{l}\text { Giza 84 // Giza 74 / } \\
\text { Giza 68 }\end{array}$ & $\begin{array}{l}\text { High seed cotton yield, lint yield, early } \\
\text { and extra long staple fiber quality. }\end{array}$ \\
\hline Giza 93 & $\begin{array}{c}\text { Extra long, extra } \\
\text { fine staple }\end{array}$ & Giza 77 / Pima S7 & $\begin{array}{l}\text { Extra-fine extra-long staple fiber } \\
\text { quality. }\end{array}$ \\
\hline Giza 96 & Extra long staple & \{Giza 84 x(Giza 70 x & $\begin{array}{l}\text { High seed cotton yield, lint yield, lint } \\
\text { percentage and extra long staple fiber } \\
\text { quality. }\end{array}$ \\
\hline
\end{tabular}

were weighted. The roots (tap and lateral) and shoots were dried for $72 \mathrm{~h}$ at $60^{\circ} \mathrm{C}$, and the dry weight was recorded for root dry weight (RDW) in $\mathrm{g}$ and shoot dry weight (SDW) in $\mathrm{g}$, and the root-shoot ratio (RSR) was calculated. Growth rate (GR) was calculated according to the equation described by Medany et al.(2007).

\subsection{Chemical component of cottonseed}

The oil and protein content of seeds for each genotype were determined by Soxhlet and Kjeldahl methods, respectively. The samples for oil and protein content were analyzed in six replicates, and their means were considered in the statistical analysis. Nitrogen percentage was multiplied by a constant factor (6.25) for calculating protein content. Also ash content was determined. All these chemical analyses were determined based on the methods described by the Association of Official Analytical Chemists (AOAC, 2004). Carbohydrates were was estimated by substraction, these chemical analyses were made in Cotton Chemistry Department, the Cotton Research Institute, Agriculture Research Center, Giza, Egypt.

\subsection{Statistical analysis}

The recorded data were statistically analyzed using Fisher's analysis of variance techniques ANOVA and LSD test was applied at $5 \%$ and $1 \%$ probability levels to compare the differences of phenotypic mean expression between the eight Egyptian cotton genotypes.
The genetic components of variance were computed using mean squares and calculated. The Mahalanobis $\mathrm{D}^{2}$ statistic between the Egyptian cotton varieties using all studied characters based on Toucher's method as was out-lined by Rao (1952). Testing the significance of dissimilarity $\mathrm{D}^{2}$ using Chi-square technique was performed according to Singh and Chaudhary, (1979). Phenotypic correlation coefficients were also calculated between all the studied characters. The genetic dissimilarity coefficients between and within all these studied characters on the basis of squared Euclidean distance were calculated as outlined by Johnson and Wichern (1998).

\section{RESULTS AND DISCUSSION}

The phenotypic mean expression of the agronomic studied characters among the eight Egyptian cotton varieties is shown in Table (2). From this table, it can be seen that some agronomic characters of the eight Egyptian cotton varieties such as, lint percentage, seed index and lint index ranged from 40.719, 11.975 and 8.242 to $34.218,9.238$ and 4.807 for Giza 94 and Giza 92, respectively. Seed volume ranged from 12.667 for Giza 94 to 8.833 for Giza 87. Giza 92 and Giza 96, had the least seed index. While, seed density ranged from 0.951 to 1.222 for Giza 94 and Giza 96, respectively. The results agree with El-Kadi et al., (2013) and Attia (2015). 
Table (2): Phenotypic expression means of the agronomic, chemical cotton seed components and seedling vigour for the studied characters among eight Egyptian cotton varieties .

\begin{tabular}{|c|c|c|c|c|c|c|c|c|c|c|c|}
\hline Characters & $\begin{array}{c}\text { Giza } \\
90\end{array}$ & $\begin{array}{c}\text { Giza } \\
86\end{array}$ & $\begin{array}{c}\text { Giza } \\
94\end{array}$ & $\begin{array}{c}\text { Giza } \\
87\end{array}$ & $\begin{array}{c}\text { Giza } \\
88\end{array}$ & $\begin{array}{c}\text { Giza } \\
92\end{array}$ & $\begin{array}{c}\text { Giza } \\
93\end{array}$ & $\begin{array}{c}\text { Giza } \\
96\end{array}$ & Mean & $\begin{array}{c}\text { L.S.D } \\
\text { at } \\
0.05\end{array}$ & $\begin{array}{c}\text { L.S.D } \\
\text { at } \\
\mathbf{0 . 0 1}\end{array}$ \\
\hline \multicolumn{12}{|c|}{ Agronomic characters } \\
\hline SCY $\mathbf{g}$ & 155.96 & 119.61 & 181.20 & 137.20 & 149.27 & 144.93 & 144.00 & 152.33 & 148.07 & 8.828 & 13.037 \\
\hline LY g & 62.400 & 46.250 & 73.714 & 48.733 & 54.990 & 49.612 & 51.833 & 59.907 & 55.93 & 3.434 & 5.071 \\
\hline L\% & 39.944 & 38.706 & 40.719 & 35.563 & 36.813 & 34.218 & 35.995 & 39.326 & 37.66 & 0.648 & 0.958 \\
\hline SI g & 10.675 & 10.830 & 11.975 & 9.685 & 9.603 & 9.238 & 9.757 & 9.547 & 10.16 & 0.411 & 0.607 \\
\hline LI & 7.103 & 6.843 & 8.242 & 5.356 & $\mathbf{5 . 5 8 7}$ & 4.807 & 5.487 & 6.181 & 6.201 & 0.302 & 0.445 \\
\hline$S V \mathrm{~cm}^{3}$ & 10.333 & 10.500 & 12.667 & 8.833 & 8.333 & 7.833 & 9.167 & 7.833 & 9.438 & 0.434 & 0.641 \\
\hline SD & 1.035 & 1.033 & 0.951 & 1.100 & 1.168 & 1.188 & 1.067 & 1.222 & 1.095 & 0.062 & 0.091 \\
\hline \multicolumn{12}{|c|}{ Chemical cottonseed components \% } \\
\hline Protein \% & 33.967 & 32.033 & 30.433 & 25.233 & 27.033 & 25.367 & 26.900 & 31.067 & 29.004 & 1.587 & 2.343 \\
\hline T. Carb \% & 42.530 & 45.304 & 45.209 & 49.130 & 48.704 & 49.835 & 49.477 & 45.492 & 46.960 & 1.662 & 2.455 \\
\hline Oil \% & 22.547 & 21.708 & 23.393 & 24.675 & 23.305 & 23.847 & 22.698 & 22.488 & 23.08 & 0.594 & 0.878 \\
\hline Ash \% & 0.957 & 0.954 & 0.965 & 0.962 & 0.958 & 0.952 & 0.925 & 0.953 & 0.953 & 0.009 & 0.014 \\
\hline \multicolumn{12}{|c|}{ Seedling vigor characters } \\
\hline FSW g & 1.178 & 1.025 & 1.275 & 1.068 & 1.440 & 0.927 & 0.853 & 0.964 & 1.09 & 0.122 & 0.181 \\
\hline FRW g & 0.328 & 0.228 & 0.278 & 0.275 & 0.280 & 0.382 & 0.267 & 0.247 & 0.29 & 0.042 & 0.062 \\
\hline SL $\mathbf{c m}$ & 9.642 & 10.333 & 10.883 & 8.250 & 11.233 & 7.800 & 9.533 & 8.650 & 9.54 & 0.417 & 0.616 \\
\hline RL $\mathbf{c m}$ & 6.000 & 6.517 & 6.383 & 5.250 & 6.667 & 5.817 & 4.750 & 4.542 & 5.74 & 0.538 & 0.795 \\
\hline DSW g & 0.225 & 0.182 & 0.263 & 0.195 & 0.267 & 0.203 & 0.200 & 0.207 & 0.218 & 0.021 & 0.030 \\
\hline DRW g & 0.060 & 0.060 & 0.063 & 0.067 & 0.077 & 0.067 & 0.087 & 0.062 & 0.068 & 0.007 & 0.011 \\
\hline RSR & 0.268 & 0.336 & 0.240 & 0.345 & 0.317 & 0.328 & 0.433 & 0.296 & 0.320 & 0.040 & 0.060 \\
\hline GR & 0.012 & 0.010 & 0.010 & 0.010 & 0.013 & 0.011 & 0.011 & 0.011 & 0.011 & 0.001 & 0.002 \\
\hline
\end{tabular}

$\mathrm{SCY}=$ seed cotton yield, $\mathrm{LY}=$ lint yield, $\mathrm{L} \%=$ lint $\%, \mathrm{SI}=$ seed index, $\mathrm{LI}=$ lint index, $\mathrm{SV}=$ seed volume, $\mathrm{SD}=$ seed density, $\mathrm{FSW}=$ fresh shoot weight, FRW= fresh root weight, $\mathrm{SL}=$ shoot length, $\mathrm{RL}=$ root length, $\mathrm{DSW}=$ dry shoot weight, $\mathrm{DRW}=\mathrm{dry}$ root weight, $\mathrm{RSR}=$ root shoot ratio and $\mathrm{GR}=$ growth rate.

The chemical components of seed cotton characters Table (2) showed that the protein content ranged from 33.967 for Giza 90 to $25.233 \%$ for Giza 87. Oil content ranged from 21.708 for Giza 86 to $24.675 \%$ for Giza 87 and carbohydrate ranged from 42.530 to $49.583 \%$ for Giza 90 and Giza 92, respectively. El-Kadi et al. (2013) studied oil content in four Egyptian cotton varieties ranged from 19.73 to 21.85 .

Also, Attia (2015) found that oil and protein content ranged from 19.73 to $22.0 \%$ and from 17.2 to $21.1 \%$, respectively, in six Egyptian cotton varieties.

The seedling vigour characters play an important role for obtaining optimum plant stand. Table (2) showed the seedling vigor for all the studied genotypes. The mean performance of these studied genotypes showed that shoot length (SL) ranged from 7.800 to $10.883 \mathrm{~cm}$ between Giza 94 and Giza 92, 
respectively and root length (RL) ranged from 4.542 for Giza 96 to $6.667 \mathrm{~cm}$ for Giza 88 . While, root shoot ratio (RSR) ranged from 0.296 for Giza 96 to 0.433 for Giza 93.

The analysis of variance showed that mean squares of the eight Egyptian cotton varieties were highly significant for all the studied characters as shown in Table (3), which suggested the importance of genetic variations for these characters among the studied genotypes. Similar significant differences were reported by El-Kadi et al. (2013) and Iqbal et al., (2015). Also, Malik et al. (2011) and Rezaee et al. (2015) found a wide degree of variation within species in response to seedling growth traits.

The genetic components of variations for all the studied characters are given in Table (3). The genotypic variance was greater than the environmental variance for the studied characters. The ratio between genotypic variance and total phenotypic variance, heritability in broad sense, ranged from moderate to high values for all the studied characters, reflecting the greater effect of genotypic variance for these genotypes. Malik et al. (2011) found that broad sense heritability was higher than narrow sense heritability for seedling traits in some cotton crosses.

The genetic divergence was estimated using Mahalanobis $\mathrm{D}^{2}$ statistic to calculate genetic dissimilarity coefficients among eight Egyptian cotton varieties as shown in Fig. (1) and Table (4). $\mathrm{D}^{2}$ values ranged from 4.412 to 67.571 , corresponding to all possible combinations among the studied cotton varieties taking two genotypes at a time. These estimates were treated by Chi-square values, which showed that most of the dissimilarity coefficients were significant or highly significant as described by Singh and Chaudhary (1979). The highest genetic dissimilarity coefficient was between Giza 86 and Giza 94 while, the lowest among Giza 92 and Giza 93 (Table 4). These results reflect that the high $\mathrm{D}^{2}$ value was due to the genetic dissimilarity, while low $\mathrm{D}^{2}$ values reflect genetic similarity among these varieties. According to the classification of Egyptian cotton varieties into two classes (long and extra long staple); there was highly significant dissimilarity coefficient between the two categories. While, there was no significant dissimilarity between the extra long staple varieties. These results may be reflecting the phenotypic differences between these varieties or their origin and pedigree. Abd El-Moghny et al. (2014) found significant and highly significant dissimilarity coefficient between twenty Egyptian cotton genotypes belonging to $G$. barbadense, related to their phenotypic performance.

Phenotypic correlation between all agronomic, chemical cottonseed components and seedling vigor characters are presented in Table (5). The results showed a positive highly significant correlation between most of the agronomic characters. Similar results were found by Groves and Bourland (2010). Maximum highly significant negative correlations were found between carbohydrate (0.659 to -0.973 ) and lint percentage, seed index, lint index and protein content. Also, a high significant negative correlation was found between oil content and lint percentage and protein content $(-0.546$ and -0.754), respectively. The content of seed protein is associated with the seed volume, lint index and seed index that has a considerable contribution to lint yield and lint percentage as reported by Pahlavani et al. (2008).

Highly positive correlation was recorded between oil content and carbohydrate content (0.583), while, there were highly significant negative correlations between protein content with carbohydrate and oil content. These results are in agreement with the phenotypic mean expression in Table (2). Ashokkumar and Ravikesavan (2010 and 2011) found that seed oil percentage was not correlated with seed agronomic properties, expect lint percentage and there was a highly significant negative correlation between seed protein and oil content. There was a positive significant correlation between seed volume, seed density and growth ratio. Rezapour et al. (2013) confirmed that seed size is one of the most important characteristics of seeds that can affect germination, ground cover, performance of plant and seed development duration.

Significant positive correlation among the studied characters suggested that selection may be useful for the enhancement of these correlated characters through cotton breeding programme. Iqbal et al. (2015) reported that highly significant correlations of seed characters with seedling vigor showed the possibility of quick selection on the basis of seed characters. This may reduce the time and money for developing high yielding cotton varieties. 
Table (3): Analysis of variance and genetic components for the agronomic, chemical cotton seed components and seedling vigor characters of eight Egyptian cotton varieties.

\begin{tabular}{|c|c|c|c|c|c|c|c|c|c|c|c|}
\hline \multirow{3}{*}{$\begin{array}{l}\text { Characters } \\
\text { d.f }\end{array}$} & \multicolumn{3}{|c|}{ S.O.V. } & \multicolumn{8}{|c|}{ Genetic components } \\
\hline & $\mathbf{R}$ & G & $\mathbf{E}$ & \multirow{2}{*}{$\begin{array}{c}\% \text { of } \\
\mathbf{V}\end{array}$} & \multirow{2}{*}{ E V } & \multirow{2}{*}{ GV } & \multirow{2}{*}{ Ph V } & \multirow{2}{*}{ GCV } & \multirow{2}{*}{ ECV } & \multirow{2}{*}{ PCV } & \multirow{2}{*}{ HBS } \\
\hline & 5 & 7 & 35 & & & & & & & & \\
\hline \multicolumn{12}{|c|}{ Agronomic characters } \\
\hline SCY & 283.168 & $1829.37 * *$ & 249.760 & 55.766 & 41.627 & 263.27 & 304.89 & 10.958 & 4.357 & 11.79 & 86.347 \\
\hline LY & 42.700 & $494.585^{* *}$ & 37.786 & 69.268 & 6.298 & 76.133 & 82.43 & 15.601 & 4.487 & 16.23 & 92.360 \\
\hline $\mathbf{L} \%$ & 0.330 & $32.72 * *$ & 1.347 & 82.435 & 0.225 & 5.230 & 5.454 & 6.072 & 1.258 & 6.201 & 95.883 \\
\hline SI & 0.268 & $5.085 * *$ & 0.541 & 63.699 & 0.090 & 0.757 & 0.847 & 8.562 & 2.955 & 9.057 & 89.355 \\
\hline $\mathbf{L I}$ & 0.100 & $7.659 * *$ & 0.292 & 83.357 & 0.049 & 1.228 & 1.277 & 17.871 & 3.555 & 18.221 & 96.193 \\
\hline SV & 0.338 & $16.426 * *$ & 0.604 & 83.432 & 0.101 & 2.637 & 2.738 & 17.206 & 3.362 & 17.532 & 96.322 \\
\hline SD & 0.007 & $0.051 * *$ & 0.012 & 43.346 & 0.002 & 0.006 & 0.008 & 7.292 & 4.120 & 8.375 & 75.807 \\
\hline \multicolumn{12}{|c|}{ Chemical cottonseed components } \\
\hline Protein & 22.013 & $65.024 * *$ & 8.068 & 53.699 & 1.345 & 9.493 & 10.837 & 10.623 & 3.998 & 11.350 & 87.592 \\
\hline T. Carb & 16.5946 & $42.806 * *$ & 8.8564 & 43.264 & 1.476 & 5.658 & 7.134 & 5.065 & 2.587 & 5.688 & 79.310 \\
\hline Oil & 1.622 & $5.093 * *$ & 1.132 & 42.764 & 0.189 & 0.660 & 0.849 & 3.520 & 1.882 & 3.992 & 77.780 \\
\hline Ash & 0.001 & $0.001 * *$ & 0.0003 & 34.854 & 0.0000 & 0.0001 & 0.0002 & 1.077 & 0.702 & 1.286 & 70.177 \\
\hline \multicolumn{12}{|c|}{ Seedling vigor characters } \\
\hline FSW & 0.076 & $5.093^{* *}$ & 0.048 & 43.811 & 0.008 & 0.030 & 0.038 & 15.935 & 8.198 & 17.920 & 79.073 \\
\hline FRW & 0.011 & $0.014 *$ & 0.006 & 28.303 & 0.001 & 0.001 & 0.002 & 13.138 & 10.708 & 16.949 & 60.088 \\
\hline SL & 0.275 & $9.253^{* *}$ & 0.557 & 75.631 & 0.093 & 1.449 & 1.542 & 12.619 & 3.194 & 13.017 & 93.980 \\
\hline RL & 1.216 & $3.948^{* * *}$ & 0.928 & 41.739 & 0.155 & 0.503 & 0.658 & 12.357 & 6.852 & 14.130 & 76.485 \\
\hline DSW & 0.0005 & $0.006^{* *}$ & 0.001 & 45.753 & 0.000 & 0.001 & 0.001 & 12.771 & 6.894 & 14.513 & 77.436 \\
\hline DRW & 0.000 & $0.001^{*}$ & 0.0002 & 31.747 & 0.000 & 0.000 & 0.000 & 11.269 & 8.067 & 13.858 & 66.118 \\
\hline RSR & 0.006 & $0.020^{* *}$ & 0.005 & 39.527 & 0.001 & 0.002 & 0.003 & 15.507 & 9.203 & 18.032 & 73.954 \\
\hline GR & 0.00001 & $0.00002 *$ & 0.00001 & 29.041 & 0.000 & 0.000 & 0.000 & 12.143 & 9.473 & 15.401 & 62.169 \\
\hline
\end{tabular}

The genetic dissimilarity coefficients between and within agronomic, chemical cotton seed components and seedling vigour characters are shown in Table (5). The dissimilarity within the agronomic characters ranged from 2.88 to 418.26 between seed index and seed volume and seed density and seed cotton yield, respectively. These characters showed highly significant dissimilarity, except between seed index with lint index and seed volume. Also, within the chemical cotton seed component characters, the dissimilarity ranged from 19.858 between dissimilarity ranged from 19.858 between protein and oil to 130.32 between carbohydrate and ash. So, there was a highly significant variation within these characters, except oil and protein content. Dissimilarity coefficient within seed vigour characters was between growth ratio and dry root weight ( 0.16 to 27.15$)$ between growth ratio and shoot length, it showed high similarity coefficient.

The genetic dissimilarity coefficient between all the studied characters is illustrated in Table (5). 
Table (4):Genetic dissimilarity coefficient $\left(\mathrm{D}^{2}\right)$ between the eight Egyptian cotton varieties.

\begin{tabular}{|c|c|c|c|c|c|c|c|}
\hline genotypes & Giza 86 & Giza 94 & Giza 87 & Giza 88 & Giza 92 & Giza 93 & Giza 96 \\
\hline Giza 90 & $39.965^{* *}$ & $28.213^{* *}$ & $26.292^{* *}$ & $14.379 *$ & $21.542^{* *}$ & $19.371 * *$ & 6.968 \\
\hline Giza 86 & & $67.571^{* *}$ & $20.186^{* *}$ & $31.750^{* *}$ & $27.627 * *$ & $26.205^{* *}$ & $35.711^{* *}$ \\
\hline Giza 94 & & & $51.646^{* *}$ & $37.955^{* *}$ & $45.147 * *$ & $44.111^{* *}$ & $32.702 * *$ \\
\hline Giza 87 & & & & $14.255^{*}$ & 8.105 & 8.056 & $20.553^{* *}$ \\
\hline Giza 88 & & & & & 8.521 & 6.866 & 8.894 \\
\hline Giza 92 & & & & & & 4.412 & $15.631^{*}$ \\
\hline Giza 93 & & & & & & $13.498 *$ \\
\hline
\end{tabular}

*and** Significant at 0.05 and $0.01\left(\mathrm{X}^{2}\right.$ at 0.05 and 0.01 for6 degrees of freedom=12.59 and16.81, respectively).

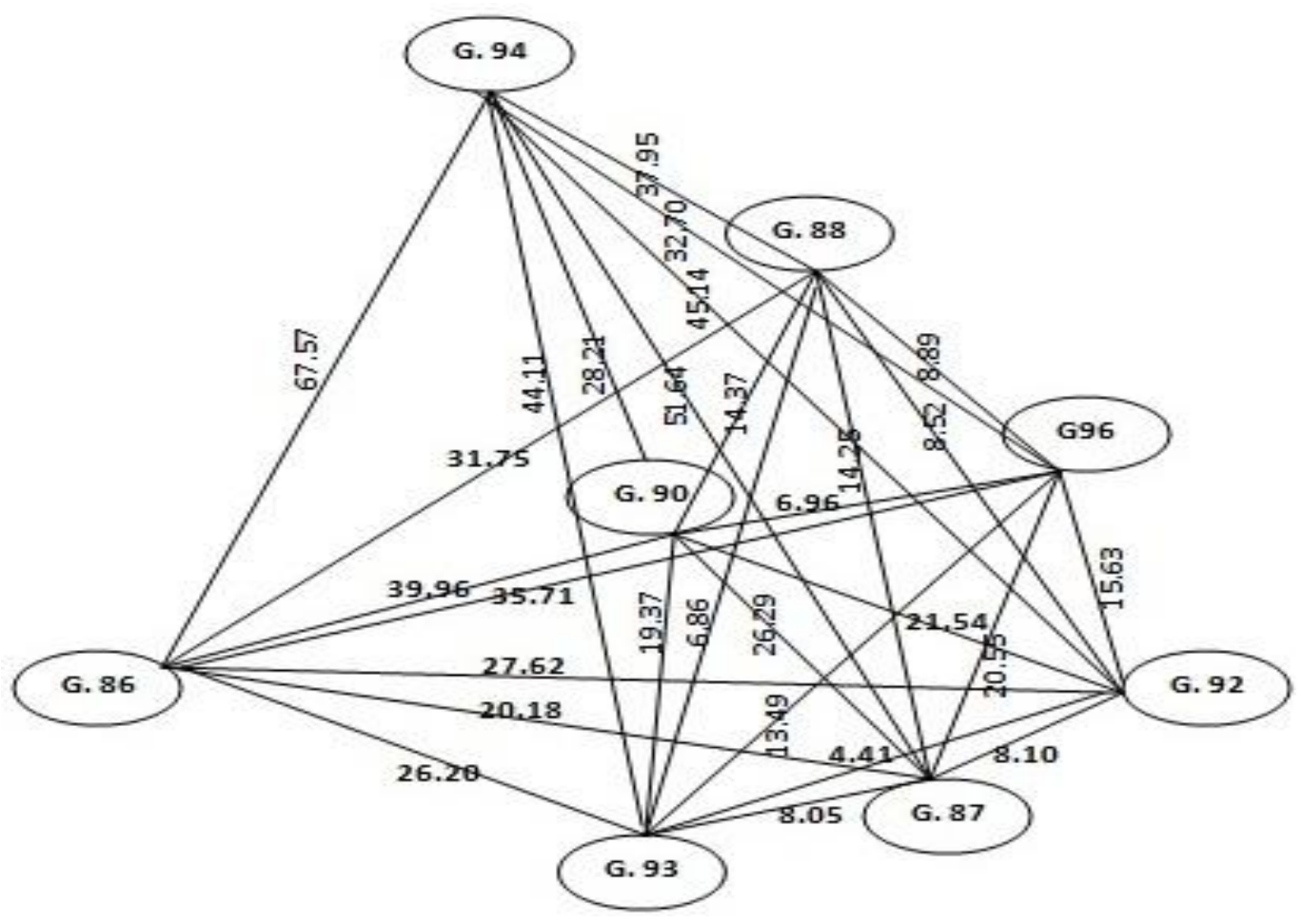

Fig. (1): Genetic divergence between the eight Egyptian cotton varieties. 
Table (5): Phenotypic correlation (below diagonal) and the genetic dissimilarity (above diagonal) between and within agronomic, chemical cottonseed components and seedling vigour among the eight Egyptian cotton varieties

\begin{tabular}{|c|c|c|c|c|c|c|c|c|c|c|c|c|c|c|c|c|c|c|c|}
\hline Traits & SCY & LY & L \% & SI & LI & SV & SD & $\mathbf{P}$ & CAR & OIL & ASH & FSW & FRW & SL & RL & DSW & DRW & RSR & GR \\
\hline SCY & & 261.79 & 315.30 & 392.65 & 403.74 & 394.61 & 418.26 & 339.83 & 290.09 & 356.45 & 418.65 & 418.24 & 420.53 & 394.44 & 405.19 & 420.72 & 421.14 & 420.45 & 421.30 \\
\hline LY & 0.94 & & 55.36 & 131.39 & 142.34 & 133.28 & 156.96 & 79.11 & 38.23 & 96.01 & 157.34 & 156.92 & 159.21 & 133.19 & 143.94 & 159.39 & 159.82 & 159.13 & 159.98 \\
\hline L\% & 0.48 & 0.74 & & 77.91 & 89.05 & 79.95 & 103.61 & 24.85 & 29.32 & 41.96 & 104.01 & 103.61 & 105.90 & 79.71 & 90.49 & 106.08 & 106.51 & 105.80 & 106.67 \\
\hline SI & 0.46 & 0.65 & 0.78 & & 11.25 & 2.88 & 25.79 & 53.81 & 104.45 & 36.75 & 26.16 & 25.76 & 28.05 & 3.19 & 12.72 & 28.23 & 28.66 & 27.96 & 28.82 \\
\hline LI & 0.52 & 0.76 & 0.93 & 0.95 & & 9.40 & 14.79 & 64.84 & 115.69 & 47.97 & 15.14 & 14.73 & 17.00 & 9.86 & 3.19 & 17.18 & 17.60 & 16.92 & 17.76 \\
\hline SV & 0.44 & 0.60 & 0.69 & 0.99 & 0.90 & & 24.04 & 55.84 & 106.62 & 38.98 & 24.39 & 23.98 & 26.26 & 3.64 & 11.14 & 26.44 & 26.86 & 26.17 & 27.02 \\
\hline SD & -0.27 & -0.41 & -0.52 & -0.89 & -0.76 & -0.95 & & 79.43 & 129.91 & 62.24 & 0.47 & 0.62 & 2.30 & 24.13 & 13.33 & 2.50 & 2.92 & 2.21 & 3.08 \\
\hline $\mathbf{P}$ & 0.17 & 0.46 & 0.89 & 0.61 & 0.78 & 0.52 & -0.41 & & 53.15 & 19.86 & 79.82 & 79.42 & 81.70 & 55.64 & 66.35 & 81.88 & 82.31 & 81.61 & 82.47 \\
\hline CAR & -0.28 & -0.56 & -0.91 & -0.66 & -0.82 & -0.57 & 0.45 & -0.97 & & 67.80 & 130.32 & 129.94 & 132.20 & 106.20 & 116.85 & 132.40 & 132.82 & 132.10 & 132.98 \\
\hline OIL & 0.22 & -0.03 & -0.55 & -0.29 & -0.41 & -0.22 & 0.17 & -0.75 & 0.58 & & 62.64 & 62.25 & 64.52 & 38.60 & 49.17 & 64.72 & 65.14 & 64.43 & 65.30 \\
\hline ASH & 0.27 & 0.35 & 0.37 & 0.37 & 0.41 & 0.29 & -0.11 & 0.22 & -0.38 & 0.31 & & 063 & 1.89 & 24.51 & 13.71 & 2.08 & 2.50 & 1.80 & 2.67 \\
\hline FSW & 0.43 & 0.47 & 0.37 & 0.38 & 0.40 & 0.34 & -0.21 & 0.16 & -0.25 & 0.15 & 0.65 & & 2.34 & 24.08 & 13.28 & 2.51 & 2.94 & 2.27 & 3.10 \\
\hline FRW & 0.24 & 0.03 & -0.41 & -0.25 & -0.31 & -0.21 & 0.20 & -0.28 & 0.19 & 0.45 & 0.07 & -0.03 & & 26.39 & 15.58 & 0.24 & 0.63 & 0.24 & 0.79 \\
\hline SL & 0.27 & 0.41 & 0.54 & 0.61 & 0.59 & 0.58 & -0.51 & 0.38 & -0.33 & -0.40 & 0.16 & 0.72 & -0.43 & & 11.03 & 26.57 & 26.99 & 26.29 & 27.15 \\
\hline $\mathbf{R L}$ & 0.06 & 0.14 & 0.23 & 0.50 & 0.39 & 0.48 & -0.40 & 0.21 & -0.23 & -0.08 & 0.54 & 0.72 & 0.13 & 0.66 & & 15.76 & 16.19 & 15.49 & 16.35 \\
\hline DSW & 0.77 & 0.72 & 0.36 & 0.36 & 0.39 & 0.33 & -0.17 & 0.07 & -0.15 & 0.18 & 0.40 & 0.85 & 0.13 & 0.66 & 0.50 & & 0.43 & 0.36 & 0.59 \\
\hline DRW & -0.06 & -0.25 & -0.54 & -0.41 & -0.50 & -0.30 & 0.14 & -0.60 & 0.69 & 0.15 & -0.73 & -0.11 & -0.04 & 0.13 & -0.26 & 0.11 & & 0.73 & 0.16 \\
\hline RSR & -0.62 & -0.74 & -0.69 & -0.57 & -0.68 & -0.46 & 0.22 & -0.55 & 0.68 & -0.01 & -0.83 & -0.60 & -0.16 & -0.26 & -0.46 & -0.56 & 0.75 & & 0.89 \\
\hline GR & 0.32 & 0.19 & -0.11 & -0.29 & -0.29 & -0.45 & 0.49 & -0.06 & 0.04 & 0.12 & -0.01 & 0.41 & 0.46 & 0.08 & 0.03 & 0.53 & 0.27 & -0.15 & \\
\hline
\end{tabular}

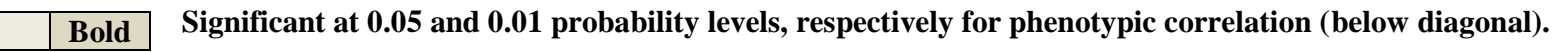

\footnotetext{
Bold Significant at 0.05 and $0.01\left(\mathrm{X}^{2}\right.$ at 0.05 and 0.01 for 17 degrees of freedom $=27.59$ and 33.41, respectively) for genetic dissimilarity (above diagonal).
} 
The dissimilarity between agronomic and chemical cottonseed components characters ranged from 0.473 between seed density and ash to 418.65 between seed cotton yield and ash. Most of these characters showed highly significant dissimilarity coefficient except, seed index, lint index, seed volume, seed density with ash. Also, there was no significant correlation between these characters. While, between agronomic and seedling vigour characters there was highly significant dissimilarity between seed cotton yield, lint yield, lint percentage and all the seed vigour characters. The significant dissimilarity was recorded between all the studied chemical cottonseed components and seedling vigour characters, except between ash and seed vigour characters. These characters also did not show significant correlations. Abd El-Moghny et al. (2014) used Mahalanobis D ${ }^{2}$ statistic between twenty cotton genotypes and found significant and highly significant dissimilarity coefficients, which ranged from 3.263 to 190.89 , indicating highly genetic divergence between these cotton genotypes

These findings help the cotton breeders, who commonly do not look for the genetic improvement of individual traits, but for genetic improvement of a set of characters, since, it is interesting for the breeder to know that the intervention in one character can cause alteration in others. The present study showed that the differences existing among the eight Egyptian cotton varieties for most of agronomic, chemical cottonseed components and seedling vigor characters can be improved through selection during Egyptian cotton breeding programs.

\section{REFERENCES}

Abd El-Moghny A. M., Max M.S. and Gibely Reham H. A. (2014). Nature of genetic divergence among some cotton genotypes. Egypt. J. Genet. Cytol., 43:365-376.

A.O.A.C. (2004). Official Methods of Analysis of AOAC (15 ${ }^{\text {th }}$ Edition); Association of Official Analytical Chemists, USA.

Attia S. S. (2015). Studies on quantitative characters in some intraspecific cotton crosses. M. Sc. Thesis, Agric. Sci. (Agronomy), Fac. Agric., Cairo Univ., Egypt.

Ashokkumar K. and Ravikesavan R. (2010). Genetic studies of correlation and path coefficient analysis for seed oil, yield and fibre quality traits in cotton $(G$. hirsutum
L.). Austr. J. Basic and Appli. Sci., 4(11): 5496-5499.

Ashokkumar K. and Ravikesavan R. (2011). Conventional and molecular breeding approaches for seed oil and seed protein content improvement in cotton. International Res. J. Plant Sci., 2(2): 037045 .

El-Kadi D. A., El-Feki T. A., Koronfel M. A. and Mohamed A A. (2013). Biometrical analysis of combining ability in diallel cotton crosses (Gossypium barbadense L.). Egypt. J. Plant Breed. , 17(5):41-56.

Groves F. E. and Bourland F. M. (2010). Estimating seed surface area of cotton seed. J. Cotton Sci., 14: 74-81.

Iqbal M., Ui-Allah S. and Naeem M. (2015). Genetic Variability and Association between Agronomic and Biochemical Seed Traits and Seedling Vigour in Upland Cotton under Sub-Tropical Conditions. Management of land use systems for enhanced food security: conflicts, controversies and resolutions" Tropentag, September 16-18, Berlin, Germany.

Islam M. K., A. M and Dilruba S. (2013). Multivariate and genetic component analysis of new cotton (Gossypium hirsutum L.) genotypes. Bangladesh J. Progr. Sci. Tech., 11(2): 185-190.

Johnson R. A. and Wichern D. W. (1998). Applied Multivariate Statistical Analysis. $4^{t h}$ ed. Prentice-Hall, Upper Saddle River, New Jersey, USA.

Malik W., Iqbal M. Z., Khan A. A., Noor E. Qayyum A. and Hanif M. (2011). Genetic basis of variation for seedling traits in Gossypium hirsutum L. Afr. J. Biotech., 10(7): 1099-1105.

Medany M. A., Hegazy A. K. , Kabiel H. F. and Moez M. M. (2007) . Prediction of seed germination and seedling growth of four crop plants as affected by root zone temperature. World J. Agric. Scie., 3(6): 714-720.

Pahlavani M. H., Miri A. A. and Kazem G. (2008). Response of oil and protein content to seed size in cotton. Int. J. Agri. Biol., 10 (6): 643-647.

Pahlavani M. H., Miri A. A. and Kazem G. (2009). Response of oil and protein content to seed size in cotton (Gossypium hirsutum L., cv. Sahel). Plant Breeding and Seed Sci., 59: 53-64. 
Rahman H., Malik S. A. and Saleem M.(2005). Inheritance of seed agronomic traits in upland cotton under different temperature regimes. Spanish J. Agric. Res. 3(2): 22523.

Rao C. R. (1952). Advanced Statistical Methods in Biometric Research. John Wiley and Sons, New York USA.

Rezapour R., Kazemi-arbat H., Yarnia M. and Moattar P. Z. ( 2013). Effect of seed size on germination and seed vigor of two soybean (Glycin max L.) cultivars. Int. Res. J. App. and Basic Sci., 4(11): 33963401 .
Rezaee S., Moghaddam M. R. R. and Bazrgar A. B. ( 2015). Cotton seed germination as affected by salinity and priming. Indian J. Appl. Life Sci., 5 (1): 312-318.

Singh R. K. and Chaudhary B. D. (1979). Biometrical Methods in Quantitative Genetic Analysis. Kalyani Publishers, New Delhi, India.

Snider J. L., Collins G. D. , Whitaker J., Chapman K. D. , Horn P. and Grey T. L. (2014). Seed Size and Oil Content Are Key Determinants of Seedling Vigor in Gossypium hirsutum. J.Cotton Sci.,18:1-9.

$$
\begin{aligned}
& \text { التباين الوراثى والارتباط بين بعض الصفات المحصولية والمكونات الكيمائية للبذرة } \\
& \text { وصفات نمو البادرة لبعض أصناف القطن } \\
& \text { أحمد محمد عبد المغنى - ريهام حلمى على عمر جبيلى - ماريز صبحي مكس } \\
& \text { قسم بحوث تربية القطن - معهذ بحوث القطن - مركز البحوث الزراعية ـ الجيزة ـ مصر }
\end{aligned}
$$

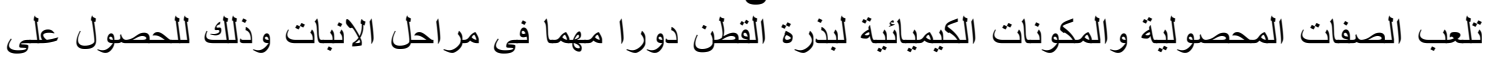

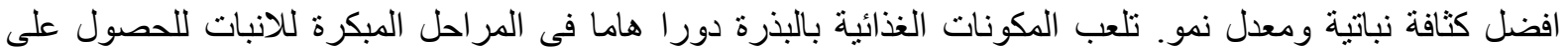

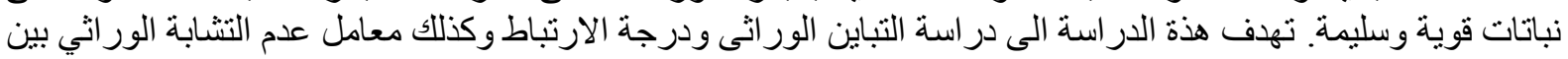

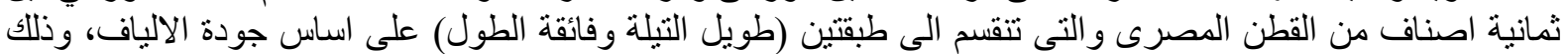

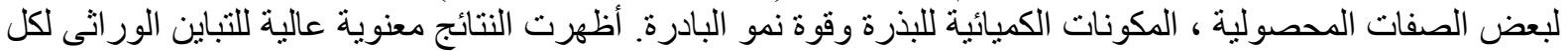

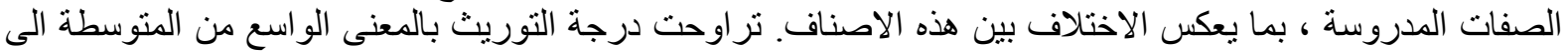

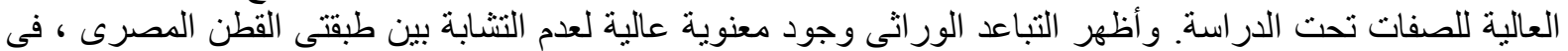

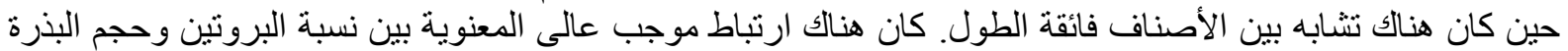

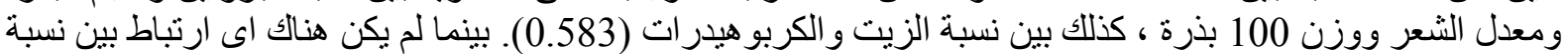

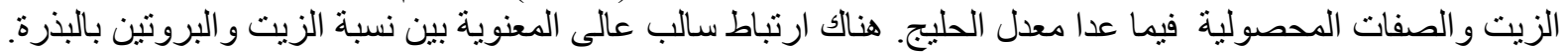

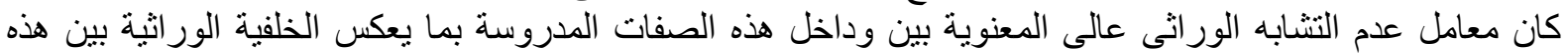

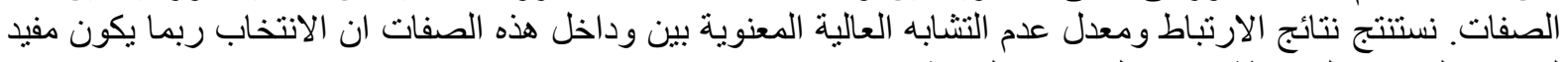

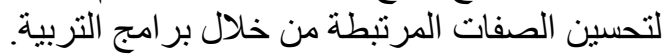

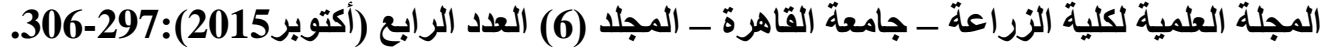

